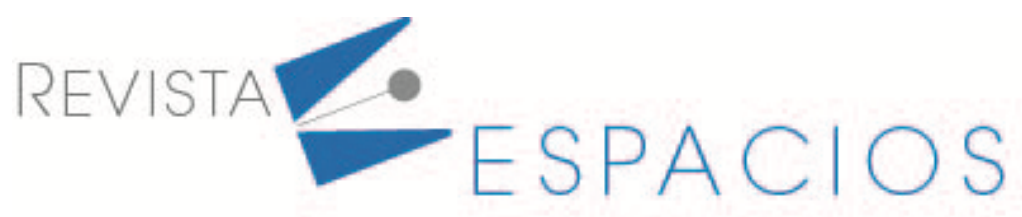

\title{
Analyzing the professional activity meanings of organizations' heads
}

\section{Analizando los significados de actividad profesional de los directores de organizaciones}

\author{
IVANOVA, Olga E. ${ }^{1}$ \\ RYABININA, Ekaterina V. ${ }^{2}$
}

\begin{abstract}
Radical changes in political, economic and spiritual spheres entail changes in valued orientations and people's professional behavior. Priorities that previously seemed immutable are replaced by different ones determining today 's reality. Personal meanings determine peculiarities of people 's behavior and relations with reality. The latter circumstance is essential for analyzing personal meanings of organizations' heads as a social phenomenon in the transforming Russian reality. The appeal to reasoning is also due to the fact that job satisfaction is not limited to economic benefits. Purpose of work: analysis of sense in the labor activity of heads of organizations. Research methods: psychodiagnostic methods: M. Rokich's "value orientation" method, E. Shein's "Career Anchor" method. Strong and weak positions of possibility of realization of the management concept on the basis of senses are revealed.
\end{abstract}

key words: personality focus, personal meaning, meaningfulness; management

\begin{abstract}
Resumen
Los cambios radicales en las esferas política, económica y espiritual implican cambios en las orientaciones valoradas y el comportamiento profesional de las personas. Las prioridades que antes parecían inmutables son reemplazadas por otras diferentes que determinan la realidad actual. Los significados personales determinan las peculiaridades del comportamiento y las relaciones de las personas con la realidad. Esta última circunstancia es fundamental para analizar los significados personales de los jefes de organizaciones como fenómeno social en la realidad rusa transformadora. La apelación al razonamiento también se debe al hecho de que la satisfacción laboral no se limita a los beneficios económicos. Objeto del trabajo: análisis de sentido en la actividad laboral de los jefes de organizaciones. Métodos de investigación: métodos de psicodiagnóstico: método de "orientación al valor" de M. Rokich, método "Career Anchor" de E. Shein. Son reveladas las posiciones fuertes y débiles de la posibilidad de la realización del concepto de dirección en razon de los sentidos.
\end{abstract}

Palabras clave: enfoque de personalidad, significado personal, significación; administración

\section{Introduction}

Today, we can observe the problem of human management from the standpoint of efficiency, benefit and, as a result, profitability of the enterprise. A person is considered a company's resource potential, which, in turn, leads to depersonalization and "erasure" of his activity meanings.

\footnotetext{
${ }^{1}$ Doctor of Philosophy. Professor. South-Urals State Humanitarian-Pedagogical University. Chelyabinsk. Russia. ivanovaoe@cspu.ru

${ }^{2}$ PhD of Pedagogical Sciences. Associate Professor. South-Urals State Humanitarian-Pedagogical University. Chelyabinsk. Russia. ryabininaev@cspu.ru
} 
The capitalist approach to personnel management is certainly not a negative phenomenon in a competitive environment and leads to increased profits [Sidorov, 2018]. However, the flip side of this phenomenon is the rapid loss of interest among employees, an increase in staff turnover (the problem of ghost workers, an unfavorable psychological climate) and a high level of organization's staff dissatisfaction.

We see the solution of the whole set of problems in changing the personnel management concept from "resource" to "meaning-forming."

The need to transform the concept of human management is a process of adapting organizational reality to the demands of an unstable environment and the emerging workforce of a new formation.

The transformation of personnel management concept is implemented in management on the basis of meanings, which is a tool to increase the company's competitiveness, to understand the meaning of employees' own work activity and to understand their own contribution to the organization development. The heart of this concept is meaning which acts as the basis of communication ( interaction and perception) between the organization's head and personnel.

It is important that this concept recognizes the employee as a subject of organizational reality and that it contributes to adaptating new generation $\mathrm{Z}$ members to work, who are prone to rapid reaction to changes and minimizing excess work.

Using these ideas as basis, the authors of the article turn to Barnet Pierce's theory of coordinated management meanings developed in the mid-1970s [Pierce, 2001]. It is rooted in social constructivism and pragmatism, which makes it possible to view meaning, as a result of interaction between the author and the audience, in our case, between the head and subordinates.

Following B.Pierce, we believe that the process of communication between managers and personnel is a collective management of generating meaning, in which the objects of the social world are not external, but a consequence of meanings reconstruction. Everyone's social world relates to its basic meanings.

In his article "On the Meaning and Significance" (1892), G. Frege [Frege, 1982] first contrasted the meaning (German: Sinn) and significance (German: Bedeutung, denotatus), although in German these words were previously used as synonyms [Anashvili, 1997] . To understand these categories, he modeled a triangle, which clearly demonstrated the relationship of concepts.

In E. Gusserl 's philosophy, the meaning (Germ. Bedeutung) is represented as a "linguistically framed" meaning (Germ. Sinn), which itself is intention (Lat. intentio "intention, aspiration"). Thus, meaning is seen as the focus of an individual 's thought activity on knowing something. In this regard, E. Gusserl brings meaning and significance closer [Gusserl,2009]. Wittgenstein was the first to point out the defining role of context in identifying meaning [Shreyder, 2000]. 
Figure 1

G.Frege's Triangle

Sign, name, symbol

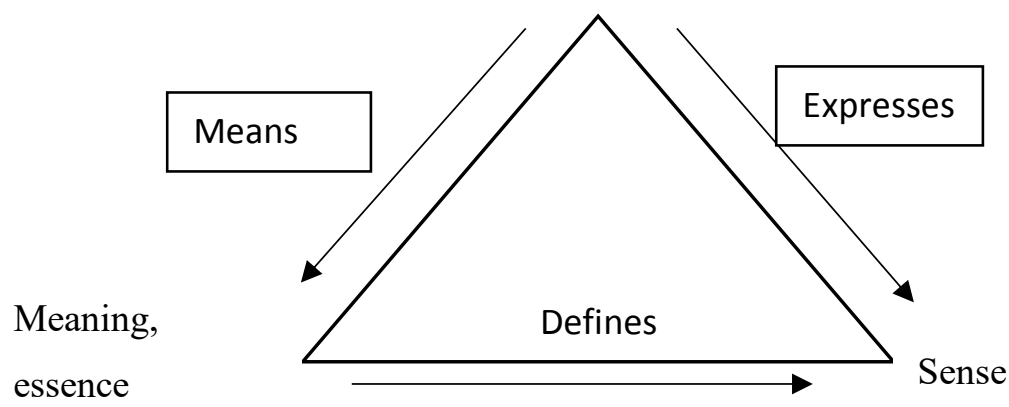

Based on this, we set the goal of the study, which is to identify the meaningfulness of the professional activities of various organizations' heads, to determine the specific meanings that they put into the management process and the need for forming meaning. Following the purpose of the study, we clarify that the subject of the study is the meaning with its specific context, which enterprises heads invest in their professional activity.

One more key concept necessary for specifying the research purpose is personal meaning which D.A. Leontiev considered as subjective meaning of a certain objective meaning [Leontiev, 2009]. This interpretation of meaning is related to the peculiarities of representing meaning in foreign psychology, where meaning is understood as the interaction of individual and social in the person.

We are interested not in the semantic definition of meaning from the point of view of transforming the concept of personnel management, but in the pragmatic definition of meaning, which evaluates this concept from the position of a person as a subject of activity. In this case the meaning is determined by value, significance, or utility characteristic. The meaning is gained in the context of professional activity, individual's needs realization and contains a component of knowledge about and attitude towards this activity.

\section{Methodology}

Survey was the main research method. It was aimed at identifying organizations heads' meanings in professional activities and their relationship with performance. The survey was conducted via the Internet on the google platform. The term of conducting the survey was January-February 2020.

The survey included 23 questions [annexes] of open and closed types. Closed questions involved the choice of one answer option, open questions gave respondents the opportunity to answer in detail. 3 questions from the questionnaire contained general statistics (No. 2,22,23), the rest were divided by the following criteria:

- Understanding and awareness of the work meaning(No. 1.3);

- Personal meaning for the head (№ 4, 5.6.7.12. 21)

- Relationship between performance and meaning (No. 8.15);

- Organizations heads" meanings in employees' work (№ 9.16);

- Meaning formation (No. 10, 11,13,14,17,18,19,20)

These categories of questions were compiled based on two independent psychodiagnostic methods. Methodology of "value orientations" (M. Rokeach) [Rokeach, 1973] defines the content side of a person's 
orientation and forms the basis of his or her relationship to the world, to other people, to himself or herself, the basis of the worldview and the core of motivation for life activity, the basis of the concept of life and "philosophy of life" and includes a system of personal value orientations. The second method - "Career Anchor" (E. Shane, translation and adaptation by V.A. Chiker, V.E. Vinokurova) - was used for diagnostics of the value component of professional activity [Chiker, 2006; Shane, 2020].

Analysis of indicators distribution according to the main criteria from 0 to $100 \%$ and its visual representation enabled the authors to identify vulnerabilities and accordingly growth points for implementing the concept of transforming organization's personnel management on the basis of meanings.

The study data were processed using descriptive statistics.

Invitations to participate in the online survey of organizations' heads were sent by e-mail and messengers (Viber, WhatsApp) and contained a direct link to the platform. The text of the message and the introductory part of the survey indicated the form and purpose of the survey, the guarantee of anonymity, the possibility of participating with the help of electronic gadgets, including mobile devices with access to the Internet.

\subsection{Sample Description}

47 people $(\mathrm{N}=47)$ : $56.5 \%$ men and $43.5 \%$ women were involved in the survey. The age of respondents was $4,3 \%$ between 21 and 30; 65.2\% between 31 and 40; and 30.4\%. between 41 and 50. It should also be noted that the majority of organizations' heads are between the ages of 31 and 40 and belong to generation $Y$ (millenials).

\section{Results}

In order to be able to implement a transformative concept of meaning-based management, it is necessary to identify the areas in which it will be most favourably "absorbed" by the organization and its weaknesses. Therefore, it is neccessary to consider each criterion in more detail.

\subsection{Understanding and awareness of the work meaning}

The first criterion of understanding and awareness of work meaning is the "Name" of the object of knowledge, i.e. its presence in the cognitive sphere of the organization head. This criterion included the questions: "Do you understand the expression "Work meaning"? And "Do you realize the meaning of your work?" the organizations' heads responded positively with $91.7 \%$ and $95.8 \%$, respectively, suggesting awareness of their professional activities. To reiterate, these questions reflect the specific character of the criterion, which makes it possible to see a common understanding of the concept of "meaning." The high performance of this criterion demonstrates the ability to work in this field.

\subsection{Personal meaning for the head}

The second criterion of personal meanings of organizations' heads in their professional activities reflects the correlation of a person with reference points, subjectively significant in a specific period of time. This criterion demonstrates the context of meanings that organizations' heads directly invest in their work.

We will try to summarize the respondents' answers to the question "What is the meaning of your work?" and identify their general trends.

1. The I-concept constituted $34.8 \%$ and included the answers "Profit", "Sales", "Self-realization", "Perform the task well". 


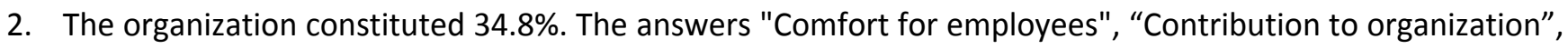
work of the organization", "Providing services for the organization", "Providing the enterprise with qualified personnel", "Managing processes the organization processes".

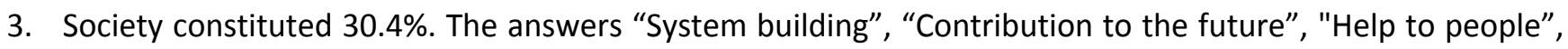
"Education management", "Protection of citizens' rights".

The field of "I concept" is a weak side of the organization, because selfish motives of this category of meanings can become an obstacle to transforming the concept of personnel management. The areas of "organization" and "society", on the contrary, are a favorable foundation where the meanings of organizations heads are identical to those of the organization.

These results demonstrate the general orientation of organizations' heads personality. It causes selectivity in human relationships and activity, and includes various inducements.

The criterion of organizations' heads personal meanings is explained by the process of identification with a specific social group, the common character of sociogenesis process leading to assigning meaning orientation, which characterizes the values of this social group. Self-awareness of a key link in constructing a system puts a person face-to-face with the system of meanings developed by the corresponding social group. By the time organizations' heads realize their affiliation with a certain organization, they already share a significant part of its meaning orientation, which, in fact, serves as a basis for identifying themselves with it. The consequence of this identification is the acceptance of other meanings and values that are part of the group's"value core".

\section{Figure 2}

The distribution of answers to the question "Do you link the meaning of your work to the meaning of your life?"

5. Do you link the meaning of your work to the meaning of your life?

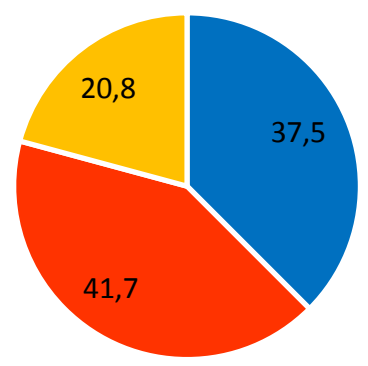

Source: IVANOVA, Olga E. and RYABININA, Ekaterina V.

As the pie chart shows the meaning of work, professional activity for most organizations' heads (41.7\%) is not related to the meaning of their lives. The personal meaning may not coincide with the life meaning, because the life meaning is an objective characteristic of the individual's attitude towards phenomena and objects, and the personal meaning is a form of subjective reflection of this attitude in the image of the world [Leontiev,2009, p.168].

$20.8 \%$ of respondents only partially establish this connection and $37.5 \%$ see the meaning of their lives in the activities implemented. Almost identical values on this issue can indicate self-realization and satisfaction with

the work of organization's heads. Some of them successfully reveal their potential in professional activity, others, on the contrary, see it in other spheres of life. 
Another important feature of the fusion of life meanings and professional activity is age parameters, which for the age of 31 to 40 will differ from others. So, this age is characterized by career desire and self-realization through profession, necessity of status and "pumping" yourself as a professional.

The coherence of the organization's head and the organization's values is related to thinking, in this regard the meaning is the necessary rational and logical basis of values. As evidence, the meaning of work for the majority of respondents $(79.2 \%)$ is directly related to their professional and personal qualities and abilities.

The statement "If I had to sum up my work today, I would say that it did not make sense" ( $95.8 \%$ of respondents answered negatively, $4.2 \%$ answered positively.) and "My work seems meaningless to me" $(87.5 \%$ of respondents answered negatively, it was difficult to answer for $12.5 \%$ ) also demonstrate the meaning of the activity and its value.

To better understand the meaning-based management process, the question "What is the most valuable thing about working for you?" was introduced. To understand the general direction of the respondents' answers, we will combine their groups:

1. Society. (Trust of people, team, communication, need, people)

2. Process and result (Result, Transparency of result, work, quality of work)

3. "I concept" (Desire, income, satisfaction, freedom/independence, mindfulness of work, opportunity to apply your knowledge).

These categories correspond to the categories of the question about work meaning and demonstrate the identity of "names," but the difference in context.

As mentioned above, these categories clearly reflect the overall focus of organizations' heads personality. Similar to the question of work meaning it is possible to see three characteristic components: communication focus, business focus, and personal focus.

Communication focus is determined by need of the organization's head for communication and interaction, aspiration to maintain the team favorable psychological climate which, in turn, will promote their growth.

The organization head's business focus is characterized by the prevalence of motives related to the achievement of the organization's goals, the increase of subordinates' productivity. A bright feature of such managers is their passion for the process of activity.

The personal focus reflects motives of organizations' heads own well-being, desire for career growth and superiority. Professional activity is limited to the possibility of satisfying their claims.

\subsection{Relationship between performance and meaning}

The third criterion reflects the process of establishing the organization heads' link between work effectiveness and meaning and makes it possible to see the "meaning" and its expression in the production of work. 
Figure 3

Distribution of responses to the question "Is there a link between performance and human value?

15. Do you think there is a connection between activity efficiency and its value for a person?

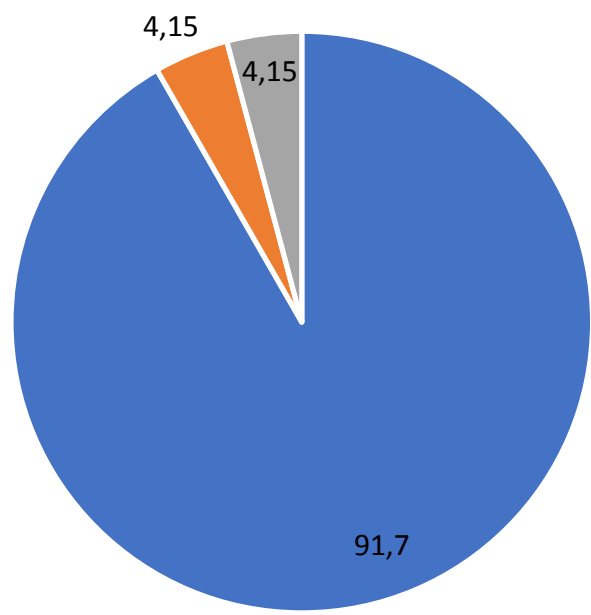

- Yes, of course

- No

- Difficult to answer

Source: IVANOVA, Olga E. and RYABININA, Ekaterina V.

The pie chart shows most organizations' heads (91.7\%) establish a correlation between performance and human value. And the minority of $8.3 \%$ attach importance to circumstances and situations. These results form a positive basis for the process of transforming the concept of personnel management, because by transmitting this focuses organizations' heads can influence their own personnel's efficiency.

\subsection{Organizations heads"' meanings in employees' work}

The fourth criterion reflects the meanings of organizations' heads in employees' work. This meaning demonstrates the "significance" for organizations' heads, generating the significance and value of their subordinates.

When asked "Do you know what is your subordinates' work meaning?" 61.5\% answered in the affirmative, 34.6\% found it difficult to answer, $3.8 \%$ answered in the negative.

Understanding employees' personal meanings provides favorable conditions for defining the company's values according to the market situation and takes the company to a new level. 
Figure 4

Distribution of answers to the question:"What do you

think is your employees' most valuable characteristics?

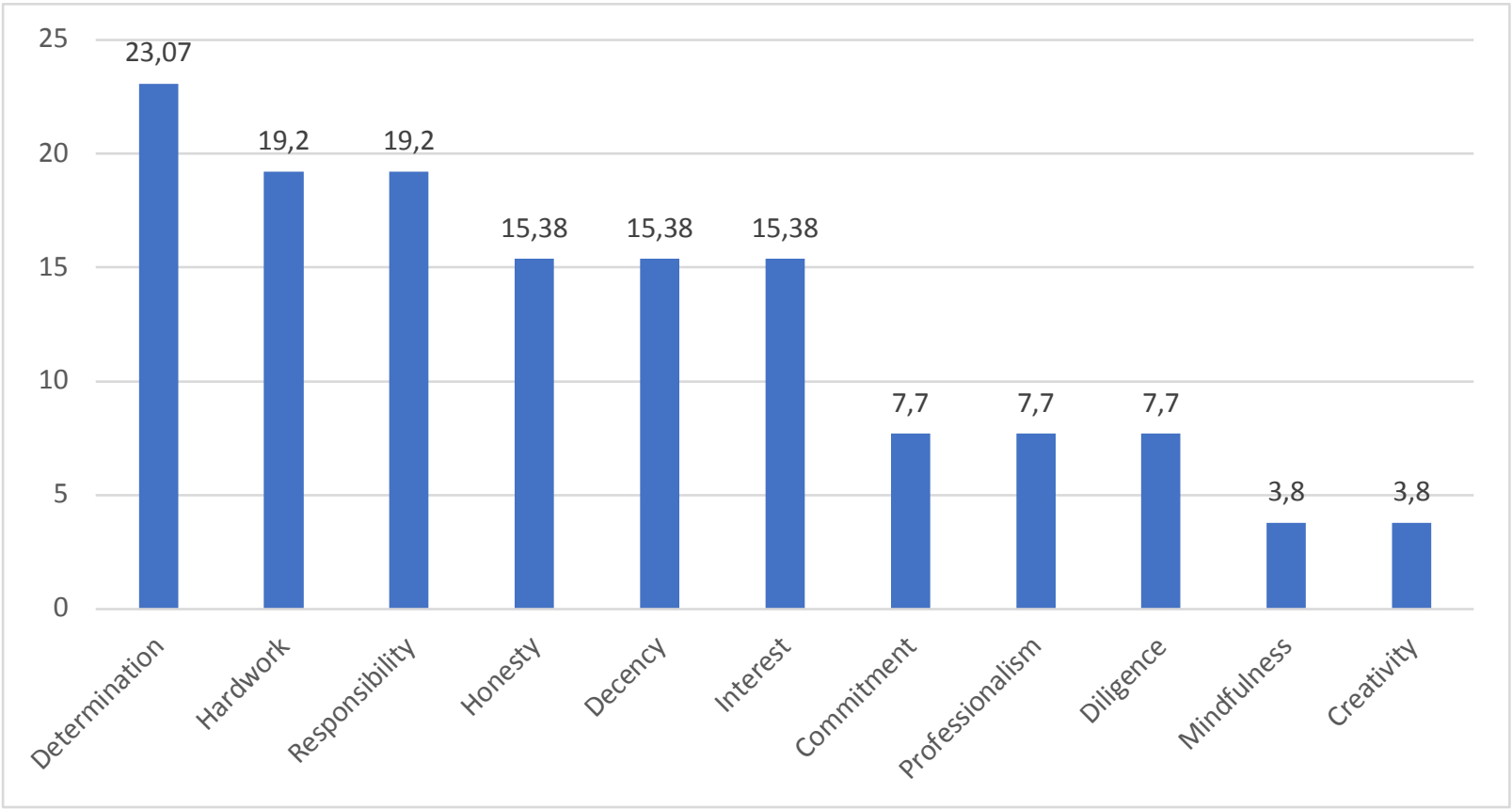

Source: IVANOVA, Olga E. and RYABININA, Ekaterina V.

The bar chart demonstrates that organizations' heads consider the following characteristics the most valuable for employees : determination(23.07\%), hard work and responsibility (19.2\%), honesty, decency and interest (15.38\%), diligence, commitment and professionalism (7.7\%). Characteristics such as mindfulness and creativity (3.8\%) are the least valuable.

This data demonstrate managers' focus on employees, as the core resource of the organization, which is certainly a vulnerable point for implementing transformation of the management concept.

\subsection{Meaning formation}

The fifth criterion is meaning formation or meaning birth, which consists of meaningful activities aimed at establishing and forming meanings.

A.N. Leontiev defines the process of meaning birth as "the identification of meaning nodes and their obtaining of a separate status" [Leontiev, 2009, p.131], i.e. " identifying the subject of leading meanings in the life- world, which become the meaning-forming basis of its life activity" [ibid. p.133].

Meaning birth is directly related to the environment. This phenomenon can be exemplified by forced work, in activities that were initially of no value and significance. In this regard, it is possible see that the answers to the question "I need to give meaning to my activities if I perform them under compulsion" were distributed as follows: Yes - $60 \%$; No $-40 \%$.

The induction of meaning is the giving of meaning (meaningful rationalization) to an activity that is initially devoid of meaning, which a person has to perform under some external coercion. The induction mechanism is expressed by the formula "people would grow to like their jobs" and is based on people's need to give meaning to everything they do. Thus, work performed under duress can gradually attract and even begin to be liked. 
Finding work meaning, identifying it and understanding it is the starting point for employees to be involved in work and organization.

Figure 5

Distribution of answers to the question "I establish the significance of something in my work deliberately"

14. I deliberately find importnat features in my work, 258 answers

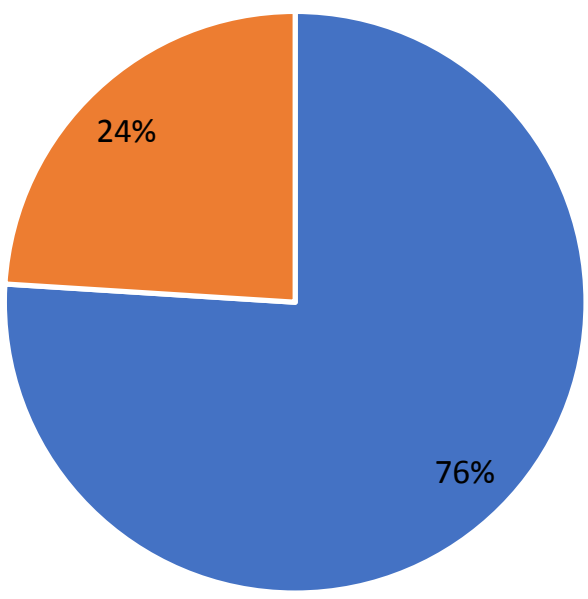

- Yes, I agree

- No, I disagree

-

Source: IVANOVA, Olga E. and RYABININA, Ekaterina V.

This pie chart demonstrates the previously described process of meanings induction as an integral part of meaning birth.

It is possible to see that the strategy of the future is also aimed at meaning birth, the desire to occupy oneself even after the work is over. $\mathbf{8 4 . 6 \%}$ of interviewees will seek meaningful retirement activities. Another indicator of meaning formation is meanings articulation, their verbalization and consolidation in the society. People seek to express their meanings verbally, discussing them in various social groups, reflecting. $57.7 \%$ answered in the affirmative; $26.9 \%$ answered in the negative and $15.4 \%$ found it difficult to answer the question "Do you talk to your loved ones about the meaning of work?"

$65.4 \%$ answered in the affirmative; $26.9 \%$; answered in the negative; $7.7 \%$ found it difficult to answer the question "Do you talk to your colleagues about the meaning of work?". $84.6 \%$ answered in the affirmative; and $15.4 \%$ answered in the negative to the question "Do you talk to your subordinates about the meaning of their work?" Yes - 84.6\%; No-15.4\%. 50\% answered in the affirmative; $38.5 \%$ answered in the negative; $11,5 \%$ found it difficult to answer the question "Does your boss talk about the meaning of your activities?".

\section{Conclusions}

The study makes it possible to draw the following conclusions:

The high indicators of the first criterion "understanding and awareness of meaning in work" reflects the common understanding of managers of the concept "meaning" and is a beneficial condition for the implementation of the concept of management based on the meaning. 
The second criterion demonstrates the context of the meanings that managers put into their work: "I-concept"; "Organization"; "Socium". Criterion of personal senses of leaders is explained by the process of identification with a concrete social group. Vulnerable to the process of implementation of the transformational concept of personnel management based on the senses are the focus of the manager's personality on himself "I-concept" in defining personal senses and perception of employees as the main resource of the company. In this regard, we should note that most managers do not connect the meaning of their life with the meaning of work. The areas of "organization" and "society", on the contrary, are a favorable foundation, where the sense of managers is identical to the sense of organization and speaks about self-actualization and satisfaction with the work of managers.

The third criterion demonstrates the connection between work efficiency and its meaning, which is reflected in the majority of positive answers $(91,7 \%)$ of managers and is undoubtedly a favorable factor for approbation of the concept of personnel management based on senses.

The understanding of the meaning of the work of their subordinates is reflected in the fourth criterion and demonstrates their importance and value. Managers see the greatest value in purposefulness (23.07\%), diligence and responsibility (19.2\%), honesty, decency and interest (15.38\%), diligence, dedication and professionalism (7.7\%). The least valuable qualities are comprehension and creativity (3.8\%). Awareness of employees' personal meanings provides favorable conditions for constructing the company's values in a coherent manner.

The fifth criterion is aimed at establishing meanings and their formation. Thus, semantic rationalization is characteristic for $60 \%$ of the interrogated. Finding meaning in work, its identification and understanding is the basis for involvement into the work activity and organization.

\section{Acknowledgment}

The research was supported by the RFBR in the framework of research project № 19-010-00322 "Transformation of the concept of human management: understanding the relationship of a person and organization in the era of post-industrialism in the light of new generation labour influx"

\section{Bibliographic references}

Chiker, V.A. (2006). Psychological diagnostics of organization and personnel. - St. Petersburg: A Speech. 176 p. - 5-926801-87-7.

Frege, G. (1892). About sense and meaning. In: Journal for Philosophy and Philosophical Criticism, N. F., Vol. 100/1, pp. 25-50.

Frege, G. (1997). Selected works: [Per. with it.] / Gotlob Frege; [Comp. V. V. Anashvili, A. L. Nikiforov]. - M.: House Intellectual, 159 p. - ISBN 5-7333-0435-9

Gusserl, E. (2009). Ideas to pure phenomenology and phenomenological philosophy. Publishing House

Academic Project. - ISBN: 978-5-8291-1042-0.

Ivanova, O.E.; Ryabinina E.V. (2019). Principles of Human Capital Management in the Light of New Generation Labor Inflow. Economics and Management: Scientific and Practical Journal. 5 (149), pp. 136-140.

Ivanova, O.E.; Ryabinina, E.V. (2019). Problems of managing young generation of workers. Azimuth of scientific research: Economics and Management. V. 8, 2 (27), pp. 150-153.

Leontiev, D.A. (2009). Psychology of Meaning. Editor: Smysl. - ISBN 978-5-89357-237-7 
Pierce, B. (2001). Brief Introduction to the Theory of Meaning Management. - Russian Communicative Association. Retrieved from: http://www.russcomm.ru/rca_biblio/p/pearce_r.shtm.

Rokeach, M. (1973). The Nature of Human Values. New York: Free Press, 1973. 438 p. - ISBN-13: 9780029267509.

Shane, E (2020). Anchor Career. Retrieved from: URL: http:// rspb.ru/professionalnaya-orientaciya/ekspressproforientaciya/test-yakorya-karery/ (date of address: 10.09.2020). - Header from the screen.

Shreyder, Yu. (2000). Meaning. New Philosophical Encyclopedia: Mysl. - Vol. 1 - 4.- ISBN 5-244-00961-3.7

Sidorov, L. G. (2018). Meaning Management as the Basis of Social Synergy. Manuscript

Tambov: Gramota.11 (97), 1, 110-114. ISSN 2618-9690.

Survey for heads of organizations/companies/enterprises https://docs.google.com/forms/d/1DuMtIAUfuV4TXEezDRBZCKV32qJQGCfF8tv0YE7kb8/edit

\section{Annexes}

\section{Survey for heads of organizations/companies/enterprises}

1. Do you understand the expression "meaning of work"?

2. How many employees do you have under your supervision?

3. Do you see (understand) the meaning of your work?

4. What is the meaning of your work?

5. Do you connect the meaning of your work with the meaning of your life?

6. My work seems to me pointless and meaningless.

7. Does the meaning of your work relate to your professional, personal qualities, abilities?

8. Do you think that by "investing" the meaning of your work/activity you can achieve more efficiency?

9. Do you know what the meaning of the work is for your subordinates/employees?

10. Do you talk to your subordinates about the meaning of their work?

11. Does your supervisor (if any) talk about the meaning of your activity/work?

12. What is most valuable to you in your work?

13. Do you talk to your colleagues about the meaning of their work (in their work)?

14. I consciously establish the importance of something in my work.

15. In your opinion, is there a connection between performance and its value to the person?

16. What is most valuable to you in your subordinates?

17. I need to give meaning to my activity (work) if I perform it under duress.

18. Do you talk with your close people, friends about the meaning of the work?

19. I do not give meaning to my work, I do as everybody does.

20. When I retire, I will try not to burden myself with anything.

21. If I had to sum up my work today, I would say that it made no sense.

22. What is your gender?

23. Your age?

Esta obra está bajo una Licencia Creative Commons Attribución-NoCommercial 4.0 International 